\title{
CONSERVATION AND MANAGEMENT FRAMEWORKS FOR SUB-ANTARCTIC INTERNATIONAL WATERS
}

\author{
by Donald R. Rothwell
}

\begin{abstract}
Rothwell, D.R. 2007 (23:xi): Conservation and management frameworks for sub-Antarctic international waters. Papers and Proceedings of the Royal Society of Tasmania 141 (1): 149-158. https://doi.org/10.26749/rstpp.141.1.149 ISSN 0080-4703.

AN U College of Law, Australian National University, Canberra, ACT 0200, Australia.
\end{abstract}

\begin{abstract}
The waters of the sub-Antarctic Southern Ocean are legally distinctive from those which fall within the Antarctic Treaty area extending to $60^{\circ} \mathrm{S}$, not only because the Treaty does not apply in those waters but also because sovereignty over sub-Antarctic islands is largely uncontested. As a result, many of the countries claiming sub-Antarctic possessions are able to assert the full range of maritime claims, resulting in sub-Antarctic waters being a mixture of state-controlled waters and those which fall under either international fisheries regimes such as the Convention on the Conservation of Antarctic Marine Living Resources (CCAMLR) or are high seas. Conservation and management of sub-Antarctic waters other than with respect to fishing have not received the same priority as they have in waters around the continent. However, the same issues arise and are in fact magnified due to the greater accessibility of the northern reaches of the Southern Ocean and potential for greater environmental and resource impact. The extent of the international waters of the Sub-Antarctic Southern Ocean is clarified here, the applicable international management regimes are reviewed and the contemporary issues confronting the region are considered. Proposals are considered for enhanced internationalisation of the region.
\end{abstract}

Key words: sub-Antarctic legal regimes, sub-Antarctic bioprospecting, sub-Antarctic maritime claims, Southern Ocean management, Southern Ocean environmental protection, sub-Antarctic fisheries regulation, sub-Antarctic "international waters".

\section{INTRODUCTION}

Primarily as a result of the application of the 1959 Antarctic Treaty the waters of the sub-Antarctic Southern Ocean are legally distinctive from that part of the Southern Ocean which encircles the Antarctic continent. The impact of Article IV of the Treaty was to place legal constraints upon the active assertion of new maritime claims within the Antarctic Treaty area. In addition, even if such claims were asserted, the ability to actually enforce national laws and regulations regulatingresource management or environmental protection was compromised by the provisions of Article VIII of the Treaty. The result has been that whilst some Antarctic Treaty claimants such as Australia have been proactive in the assertion of a range of maritime claims offshore from their Antarctic territories (Kaye \& Rothwell 2002), the claims are not widely recognised and in some instances are actively contested (Rothwell \& Scott 2007). This is not the case with respect to those sub-Antarctic waters north of $60^{\circ} \mathrm{S}$ beyond the outer limits of the Antarctic Treaty. In that part of the Southern Ocean sovereignty over sub-Antarctic islands is by and large not contested and accordingly the claimant states are not limited in their capacity to assert the full range of maritime zones, including 200-nautical-mile Exclusive Economic Zones (EEZ) and continental shelves, and in some instances claims which extend some distance beyond that limit (Jabour 2006). This provides for some certainty in determining which parts of the sub-Antarctic may truly be characterised as "international" in nature — that is waters beyond the reach of national jurisdiction which are either high seas or deep sea-bed, consistent with the provisions of the 1982 United Nations Convention on the Law of the Sea (LOS Convention).

The only part of the sub-Antarctic subject to a regional marine management framework is that over which the 1982 Convention for the Conservation of Antarctic Marine Living Resources (CCAMLR) extends. The "international management" of these sub-Antarctic waters ensures a complementarity with those Southern Ocean waters south of $60^{\circ} \mathrm{S}$, but has also created certain challenges for those states claiming islands wirhin the region and seeking ro actively regulate and enforce their fishery laws consistent not only with CCAMLR but also with their own national laws (Haward 2004). The sub-Antarctic is also subject to a range of other international management mechanisms ranging from international treaties and regimes dealing with whaling, to biodiversity conservation, to multiple forms of marine pollution, and deep sea-bed management. One of the challenges is reconciling the interests of the international community in managing these waters, with the regional interests of states who are parties to the Antarctic Treaty and CCAMLR, and with individual and distinctive national interests on the part of the sub-Antarctic states. This paper clarifies the extent of the international waters of the sub-Antarctic Southern Ocean, reviews the applicable international management regimes, and considers the contemporary issues confronting the region. Proposals are considered for enhanced internationalisation of the region.

\section{INTERNATIONAL WATERS IN THE SUB-ANTARCTIC}

\section{Identifying international waters}

Much of the modern law of the sea is directed towards confirming and clarifying the extent of coastal state sovereign rights and jurisdiction over adjacent maritime areas (Churchill \& Lowe 1999). Commencing with the territorial sea, over which coastal states have almost exclusive sovereign rights and jurisdiction subject only to the freedom of navigation by foreign ships, the law of the sea recognises a mix of sovereign rights and jurisdiction over adjacent maritime areas which extend to the outer edge of the continental shelf. Resource sovereignty is recognised over the water column, seabed and subsoil up to the limit of the 200-nautical-mile EEZ (LOS Convention, Article 56). However, beyond that limit it is 
possible for sovereign rights to be projected in the case of an extended continental shelf up to approximately 350 nautical miles from the coast (LOS Convention, Articles 76, 77).

The law of the sea (LOS) recognises that beyond the outer reaches of coastal state maritime zones there exist other maritime zones which are either subject to "international" control or may truly be classified as res communis - that is the area belonging to no single state and to which all enjoy rights of equal access (Churchill \& Lowe 1999). The first is the high seas which is the water column including the surface beyond the limit of the 200-nautical-mile EEZ. High seas freedoms are some of the most historic rights recognised under international law and traditionally extend to freedom of fishing and freedom of navigation (LOS Convention, Part VII). Under the modern law of the sea, they also extend to the freedom to conduct marine scientific research (LOS Convention, Article 87). The other regime is that dealing with the deep sea-bed, which is the "Area" beyond the limits of national continental shelf claims.

Some of the complexity that exists in identifying the international waters of the sub-Antarctic Southern Ocean are highlighted in the case of the deep sea-bed. The LOS Convention provides that "The Area and its resources are the common heritage of mankind" (Article 136) and are effectively subject to an international regime under Part XI of the Convention which confers responsibility upon the International Sea-bed Authority (ISBA) for management of the area (Joyner 1986). However, under Article 1 of the LOS Convention the "Area" constitutes that part of the sea-bed and ocean floor which is "beyond the limits of national jurisdiction"; that being the sea-bed and ocean floor which is not subject to any sovereign rights or jurisdiction of any state. Ascertaining what part of the sea-bed and ocean floor exists beyond the limits of national jurisdiction is made complex because of the capacity of coastal states to assert extended continental shelf claims. However, there is no unilateral right to assert such a claim. The LOS Convention provides that coastal states seeking to assert an extended continental shelf claim must first make a submission to the Commission on the Limits of the Continental Shelf (CLCS) which will make "recommendations" to the coastal state on matters relating to the claim. On the basis of those recommendations, the coastal state will be able to make a final claim to an extended continental shelf. Only once all potentially eligible coastal states have asserted extended continental shelf claims will the full extent of the ISBA's jurisdiction over the Area be settled.

\section{Sub-Antarctic maritime claims}

In reviewing sub-Antarctic maritime claims so as to identify by default that area of the sub-Antarctic Southern Ocean which may properly be identified as "internarional waters", it is important to distinguish the area north of $60^{\circ} \mathrm{S}$ from that to the south. That part of the Southern Ocean governed by the Antarctic Treaty up to $60^{\circ} \mathrm{S}$ raises a multitude of issues as to whether, under the Treaty, there are recognisable "coastal states", how baselines may be asserted around an icefringed continent, how new maritime zones can be asserted consistently with the modern law of the sea and the Antarctic Treaty's limitations on the assertion or enlargement of claims, in addition to the enactment and enforcement of laws and regulations which may apply to regulate activities in those maririme areas (Oude Elferink \& Rothwell 2001). None of these issues exists to the same extent in the sub-Antarctic, thereby freeing all of those states who claim sub-Antarctic possessions to assert all potential maritime claims under the law of the sea.

The various sub-Antarctic states have sought to assert the full range of maritime claims to which they are entitled under the current law of the sea. Some, such as fishing zones or EEZs, are relatively uncontroversial other than in the case of where sovereignty over the islands may be contested (e.g., South Georgia where the United Kingdom and Argentina remain in dispute (Orrego Vicuña 1996)). There is also a number of asserted claims which because of their apparent inconsistency with the LOS Convention and contemporary international law remain controversial, such as Chile's assertion of a "Presential Sea" (Orrego Vicuña 1992). Presently, one of the most contentious issues with respect to sub-Antarctic maritime claims relates to assertions of an extended continental shelf (Oude Elferink 2002).

Of the sub-Antarctic nations, Australia has perhaps been the most prominent in terms of its assertion and enforcement of maritime claims. Australia's position in terms of its subAntartic possessions - the Heard and McDonald islands, and Macquarie Island - is influenced by its position more generally with respect to maritime claims offshore the Australian Antarctic Territory (AAT). Australia has asserted a range of claims offshore the AAT which the government considers to be consistent with both its obligations under the Antarctic Treaty and the LOS Convention (Kaye \& Rothwell 2002). Australia first asserted a continental shelf claim offshore the AAT in 1953. In 1973 Australia proclaimed a three-nautical-mile territorial sea around all its territory, including the AAT, and in November 1990 extended this from three to 12 miles. Australia proclaimed an EEZ off the AAT on 1 August 1994 (Opeskin \& Rothwell 1991). Yet, Australia has adopted the somewhat ambiguous legal position of having asserted these maritime claims without actively implementing its laws within these zones. Whilst a good deal of Australian law applies within these various maritime areas offshore the AAT, there has been no instance of such law being applied to the activities of non-Australian nationals or foreign vessels. Australia has thereby sought to maintain the integrity of its claim to sovereignty over the AAT and the accompanying maritime sovereignty and jurisdiction which any coastal state enjoys over its offshore areas, whilst also respecting the limitations on the active assertion of sovereignty and jurisdiction imposed by the Antarctic Treaty.

In November 2004 Australia submitted an extended continental shelf claim to the CLCS (Downer, Ruddock \& Macfarlane 2004) which has implications for the Southern Ocean. The Australian claim will, if accepted by the CLCS, give to Australia a continental shelf of approximately 3.4 million square kilometres, which when combined with its land territories will make it one of the largest States in the world. Australia has relied upon its sub-Antarctic possessions as part of the foundation for its extended continental shelf claim in the Southern Ocean. In the Kerguelen Plateau region, Heard Island and the McDonald islands are the landmasses from which the extended continental shelf claim is based. In the Macquarie Ridge region, the Australian claim extends south from Macquarie Island to encompass an area $81719 \mathrm{~km}^{2}$ beyond the 200 -nauticalmile edge (Commonwealth of Australia 2004). Both of these asserted claims extend south beyond $60^{\circ} \mathrm{S}$ into the Antarctic Treaty area. 
The extended continental shelf claims from the Heard and McDonald islands, and Macquarie Island, may raise some concerns as to their legitimacy given the islands have no permanent population and in the case of the Heard and McDonald islands are uninhabited other than for an occasional visit by research scientists and tourists. This is significant, as Article 121 of the LOS Convention suggests that islands not capable of sustaining human habitation or an economic life of their own are more properly classified as rocks than islands and thereby not entitled to generate a claim to a continental shelf or EEZ (Kwiatkowska \& Soons 1990). Judge Vukas has already expressed his concerns in the International Tribunal for the Law of the Sea (ITLOS) regarding the legitimacy of the Australian EEZ offshore these islands (The Volga Case 2002). However, given the size of the islands and the "economic life" they have generated as a consequence of Australian licensed fishing activities in those waters (principally for Patagonian Toothfish) it is difficult to sustain a credible argument that Australia is not entitled to seek to assert an extended continental shelf. That the Australian claim purports to extend into the Antarctic Treaty area is of more significance. For Australia this raises some delicate issues under the Antarctic regime, especially with respect to the prohibition contained in the Antarctic Treaty, Article IV, on the assertion of any "new claim, or the enlargement of an existing claim, to territorial sovereignty in Antarctica" while the Treaty is in force (Kaye 2001a).

Australia has also sought to assert an extended continental shelf claim offshore the AAT. The claim seeks to enclose an area of $686821 \mathrm{~km}^{2}$ beyond the limits of the 200-nauticalmile EEZ (Commonwealth of Australia 2004). However, recognising the sensitivity that the assertion of such a claim raises for the international community and under the Antarctic Treaty, Australia requested that the CLCS not "take any action for the time being" with respect to that part of the claim offshore the AAT with the effect that the claim is effectively set aside for the time being (Jabour 2006). Nevertheless, the Australian claim generated an interesting response from other Antarctic Treaty parties, with six Germany, India, Japan, Netherlands, Russian Federation, and the United States - all lodging communications with the Secretary-General of the United Nations. Each of the communications makes direct reference to the provisions of the Antarctic Treaty, particularly Article IV, and denies recognition to rights or claims over the seabed or adjacent offshore surrounding Antarctica (Rothwell \& Scott 2007). Interestingly, the only communication relating to the Australian claim from another sub-Antarctic state was from France, and whilst the French communication does refer to the Australian claim off the Kerguelen Plateau it does not contest Australia's capacity to make such a claim (France 2005).

In 2006, New Zealand lodged a claim for an extended continental shelf. Unlike the Australian claim noted above, it excludes a claim offshore the Ross Dependency though New Zealand has reserved its position to make such a claim at a latter point in time (New Zealand 2006a). New Zealand does rely though upon Campbell Island as the basis for an extended continental shelf in the sub-Antarctic with the claim extending as far south as $57^{\circ} 34^{\prime} \mathrm{S}$ (New Zealand 2006b).

The CLCS now has both the Australian and New Zealand extended continental shelf claim under active consideration. The role of the CLCS is briefly referred to in the LOS Convention, Article 76(8) where reference is made to the need for coastal states to submit information on their extended continental shelf claims to the Commission. The Article then goes on to provide: "The Commission shall make recommendations to coastal States on matters related to the establishment of the outer limits of their continental shelf. The limits of the shelf established by a coastal State on the basis of these recommendations shall be final and binding." This rather brief provision in the LOS Convention therefore creates a quasi-judicial process in which the CLCS is effectively the "legitimator" of a coastal state's claim (McDorman 2002). The outcome of this process is the establishment of outer continental shelf limits which will have implications for the Part XI deep sea-bed regime and importantly for current purposes help to define those parts of the sea-bed which fall within sovereign jurisdiction under the continental shelf regime. It is beyond those areas - beyond the limits identified by coastal States following consultation with the CLCS - that the international sea-bed will exist. Whether other sub-Antarctic claimants seek to assert extended continental shelf claims offshore their possessions remain to be seen. In principle there is nothing to stop the other states doing so, other than where there exists disputed sovereignty, as is the case with South Georgia, or where the extended claim overlaps that asserted by another state as may arise between Australia and France in the Kerguelen Plateau.

\section{CCAMLR and the sub-Antarctic}

The CCAMLR regime extends north of $60^{\circ} \mathrm{S}$ so as to legitimately operate across the sub-Antarctic waters of the Southern Ocean. Whilst the operation of the Convention within the Antarctic Treaty area is uncontroversial given the consistency of the two legal regimes, this is not the case in the sub-Antarctic given the mixture of coastal state claims asserted offshore the islands mixed with international waters which truly fall beyond the limits of national jurisdiction. This issue was anticipated at the time of CCAMLR's negotiation and an attempt was made to harmonise the CCAMLR fisheries management regime with any fisheries laws and regulations that may have been or would be enacted in the future by sub-Antarctic claimant states (Kaye 2001b). The result was the so-called "bifocal approach" under which the laws and regulations adopted by sub-Antarctic states would continue to apply within their fishery zones and EEZs only if they expressly sought to exempt themselves from the application of relevant CCAMLR provisions (Orrego Vicuña 1996), thereby permitting those sub-Antarctic States with potential for significant fishing activities to either apply the CCAMLR regime or opt out. Notwithstanding this capacity, the practice of the principal sub-Antarctic fishing States such as Australia and France has been to work within the CCAMLR regime and indeed to actively rely upon it in their efforts to counter "Illegal Unregulated and Unreported" (IUU) fishing (Haward 2004), whilst at the same time developing management plans to ensure a sustainable fishery (Abetz 2006).

\section{What are the international waters of the sub-Antarctic?}

On the basis of the above review the following can be concluded with respect to identifying the international waters of the sub-Antarctic. With respect to the water 
column, the area includes all waters over which CCAMLR extends north of $60^{\circ} \mathrm{S}$ in addition to those waters properly classified as high seas. In relation to the sea-bed and ocean floor area of the sub-Antarctic, that part which can truly be classified as "international" remains subject to finalisation once determinations have been made by the CLCS on extended continental shelf claims and the sub-Antarctic states have formally proclaimed their extended continental shelves beyond the 200-nautical-mile limit. It may in fact take some time before the "Area" which falls within the Southern Ocean is conclusively determined; nevertheless the LOS Convention does place a time limitation upon the making of extended continental shelf claims (LOS Convention, Annex (I) and whilst there has been some modification of that process the sub-Antarctic states do not have unlimited time in which to assert their claims. That both Australia and New Zealand have submitted their Southern Ocean claims in recent years suggests there is a growing momentum amongst the sub-Antarctic states to resolve these matters soon. Only once that process is complete will it be possible to determine conclusively the "international waters" of the sub-Antarctic.

\section{Managing sub-Antarctic international waters}

The management of sub-Antarctic international waters is subject to numerous international and regional regimes. Historically, the most prominent of these regimes has been CCAMLR and as noted above this Antarctic Treaty System (ATS) instrument is unique because not only does it apply beyond the Treaty limit of $60^{\circ} \mathrm{S}$ to truly extend into the subAntarctic, but it also seeks to harmonise its provisions with the laws and regulations adopted by sub-Antarctic states. The other body whose jurisdiction is uncontested but which has yet to become truly operative is ISBA. Whilst the ISBA was one of the first institutions established under the LOS Convention, its effectiveness has been delayed somewhat until such time as the boundaries of the "Area" have been conclusively determined. Therefore, whilst theoretically the ISBA has management capacity over the sea-bed and ocean floor of the sub-Antarctic Southern Ocean, it may be some time until it actually exercises that capacity. It must be anticipated though that at some time in the future there will be interest in the exploration and exploitation of the sub-Antarctic sea-bed which will inevitably raise environmental issues and the compatibility of such activities with the prohibition on mining under the 1991 Protocol on Environmental Protection to the Antarctic Treaty (Madrid Protocol) which applies within the Antarctic Treaty area (Scovazzi 1996).

In addition to these specialist regimes for the Antarctic and the oceans, there exists an additional body of international environmental law with global, regional and sub-regional application of relevance to the sub-Antarctic. Whilst international environmental law is a relatively new area of international law (Birnie \& Boyle 2002), the Southern Ocean has long been subject to its application especially through the 1946 International Convention for the Regulation of Whaling (Whaling Convention). Through a range of "hard law" binding treaties such as the 1972 World Heritage Convention, 1973 International Convention for the Prevention of Pollution from Ships (MARPOL) and the 1992 Convention on Biological Diversity, many Southern Ocean activities have become subject to environmental regulation thereby complementing the environmental management provided for under the ATS (Rothwell 2004).

A number of these regimes has raised particular issues for the Southern Ocean generally and the sub-Antarctic more specifically. An impact of increased fishing activities under CCAMLR has been the phenomenon of seabird bycatch. This proved to be the catalyst for adoption in 2001 of a special agreement between several sub-Antarctic states dealing with conservation of albatrosses and petrels (Hall 2007). Whaling has a long history in the Southern Ocean, with respect to a vibrant industry in the nineteenth and early twentieth centuries and more recently for conservation and sustainable management of whale stocks. Under the provisions of the 1946 Whaling Convention, commercial whaling has been prohibited since the $1985 / 86$ season and in addition a "Southern Ocean Whale Sanctuary" has been adopted, the effect of which is to permanently prohibit all commercial whaling in the Southern Ocean in an area which in parts extends as far north as $40^{\circ} \mathrm{S}$. This Sanctuary is complemented by an "Indian Ocean Sanctuary" which extends as far south as $55^{\circ} \mathrm{S}$ in the Indian Ocean, thereby creating an extensive area of the Southern Ocean and adjacent waters within which all commercial whaling is prohibited.

There is currently controversy over whether the activities of Japan in the Southern Ocean are in breach of the Whale Sanctuary due to Japan's authorisation of "scientific whaling" of minke, fin and humpback whales. While Japan contends that these activities are consistent with the exemption for "scientific whaling" under the Whaling Convention, Australia and New Zealand have been actively engaged in a campaign opposing Japan's activities which has resulted in legal action being taken in the Australian courts (Blay \& Bubna-Litic 2006). Whilst to date this controversy has not had a particular sub-Antarctic focus, it does highlight the potential for disagreement over management and conservation efforts in the Southern Ocean more generally, notwithstanding the existence of the Southern Ocean Whale Sanctuary.

Controversy has also flared due to the overlap of certain resource management regimes. For example, in 2005 it was revealed that southern bluefin tuna were being harvested within the CCAMLR area of the Southern Ocean under the authorisation of a commission created under the 1993 Convention on the Conservation of Southern Bluefin Tuna. This instance of "regime overlap" highlighted the need for greater harmonisation between the various institutions with capacity for regulating fisheries in the sub-Antarctic and the potential for effective resource management to be compromised unless the institutions resolve their areas of competency and seek to minimise management conflict (Hemmings 2006). Whilst the waters of the Southern Ocean and sub-Antarctic are also the subject of multiple International Maritime Organisation (IMO) conventions and treaties regulating maritime affairs including shipping movements, marine pollution, and liability and compensation, doubts have been raised as to the adequacy of these mechanisms. These doubts centre on whether they are capable of resolving maritime disasters in the Southern Ocean given the inevitable environmental impact which will arise from such events (Zovko 2005). This is especially an issue in the light of growing vessel traffic in the region arising from tourism demand and the increased proliferation of icebergs in sub-Antarctic waters. The management of sub-Antarctic international waters is therefore the subject of multiple international and regional legal regimes. Whether they all operate in harmony is questionable. 


\section{CURRENT CHALLENGES IN THE MANAGEMENT OF SUB-ANTARCTIC WATERS}

Having identified the international waters of the subAntarctic, what are some of the current issues facing the management of these waters? The most prominent at present include bioprospecting and marine scientific research, and IUU fishing.

\section{Bioprospecting and marine scientific research}

Bioprospecting has been the subject of a number of definitions. However, it can generally be considered "a scientific exploring activity to search for something useful from nature" (Farrell $\&$ Duncan 2005 p. 13). There has been of course an historical interest in scientific research activity in Antarctica and the Southern Ocean and indeed it is upon this foundation that the Antarctic Treaty was partly founded. Whilst there has always been a commercial element to Antarctic research, bioprospecting both on the continent and within the Southern Ocean takes this issue to another dimension given the potential commercial benefits to be reaped from certain discoveries. The conduct of bioprospecting in Antarctica and the Southern Ocean is therefore an activity which has generated considerable interest in the past decade (Jabour-Green \& Nicol 2003, Hemmings \& Rogan-Finnemore 2005).

Pivotal to an understanding of the legal regime dealing with marine bioprospecting are the provisions of Part XIII of the LOS Convention dealing with marine scientific research (Guyomard 2006). Part XIII makes clear that all states have a right to conduct marine scientific research subject to the rights and duties of other states, including coastal states (Article 238). The framework which is then constructed, is as follows:

- Within the Territorial Sea the coastal state has the exclusive right to regulate marine scientific research meaning that the activity can be either prohibited, or permitted subject to regulation (Article 245).

- Within the EEZ and continental shelf the coastal state can regulate marine scientific research on the basis that in normal circumstances consent will be granted for such research to be undertaken by other States (Article 246).

- In the Area and within the water column beyond the 200nautical-mile limit, all States have the right to conduct marine scientific research (Article 256-257).

Taking into account this framework and the provisions of the law of the sea as it applies to the Southern Ocean discussed above, the following can be concluded:

- that within the Southern Ocean, sub-Antarctic States have a capacity to proclaim maritime zones

- sub-Antarctic States have the capacity to explore and exploit the water column and sea-bed

- sub-Antarctic States can legitimately seek to determine the outer limits of their continental shelf claims

- sub-Antarctic States can likewise seek to regulate marine scientific research within their adjacent territorial sea and EEZ/continental shelf areas

- that parts of the Sub-Antarctic Southern Ocean may be considered to be part of the "Area" and fall under the Part XI deep sea-bed regime (Oude Elferink \& Rothwell 2001, Joyner 1992).

Given the unique legal regime that exists in the Southern Ocean as discussed above, a legal regime for bioprospecting in the sub-Antarctic Southern Ocean could revolve around the following actors. First, coastal states play a key role as recognised by the marine scientific research provisions of Part XIII of the LOS Convention. They have a clear-cut capacity to regulate bioprospecting within the narrow 12-nauticalmile territorial sea, and further beyond to the limits of the EEZ and continental shelf. Second, so-called flag states (who register ships thereby permitting them to fly the "flag" of that state) play an important role in regulating the activities of their ships engaged in marine scientific research so as to ensure compliance not only with the general provisions of the LOS Convention but also with the 1992 Convention on Biological Diversity (CBD) (Guyomard 2006). In addition, flag states also have an important role in ensuring their ships meet the stringent marine environmental provisions which apply within the Southern Ocean including under MARPOL and the Madrid Protocol. Third, there is also a role for the international community more generally especially as envisaged under the CBD but also under the provisions of the LOS Convention dealing with the deep sea-bed and the regulation of activities in the "Area" by the ISBA. Here the role of the Conference of Parties (COP) to the $\mathrm{CBD}$ and the growing significance of the meetings of the State Parties to the Law of the Sea (SPLOS) should not be ignored (Oude Elferink 2004). Yet while these groups may comprise the major "players", there remain significant legal challenges in adequately reflecting their interests and ensuring a harmonious legal regime.

Whilst marine bioprospecting will in the majority of instances around the world either be regulated by coastal states controlling activities within their maritime zones or by flag states controlling activities on the high seas, there are significant challenges to doing so in the Southern Ocean (Guyomard 2006, Vigni 2006). This principally arises because of the variable state of the legal regimes which currently apply in the sub-Antarctic and the limited capacity many of the sub-Antarctic states have to enforce their laws and regulations which also arises in the context of fisheries matters (Molenaar 2001). What alternatives then exist to a possible legal vacuum throughout the subAntarctic dealing with marine bioprospecting? It could be anticipated that flag state enforcement of bioprospecting laws and regulations would be an adequate alternative. However this also does not present any guarantee for regulation or control of bioprospecting. Given that marine bioprospecting substantially falls under the regulation and control of coastal states within their maritime zones, if flag states do not recognize coastal state sovereignty and jurisdiction but rather consider the Southern Ocean to substantially be high seas and therefore open to all forms of marine scientific research, then the capacity to regulate ships engaged in bioprospecting is further compromised. Indeed, the view could be taken that through a combination of the LOS Convention and the CBD, much of the Southern Ocean could be considered open to bioprospecting and accordingly only subject to the most basic of controls. Under this scenario it could be anticipated that only ATS members states would respect a distinctive Southern Ocean regime regulating bioprospecting.

Further difficulties arise because of the global legal regime created under the CBD and the LOS Convention which promote both marine scientific research and bioprospecting. It could even be argued that given the potential global benefits arising from bioprospecting, such an activity is also generally consistent with the "common heritage" concept 
as it applies not only to the deep sea-bed but also to other "commons" such as outer space and the moon. When viewed against the ATS, there is a clear tension between the global regime and the regional as there is currently no framework within the Antarctic regime, the Southern Ocean or the subAntarctic to adequately regulate bioprospecting (Johnston \& Lohan 2005). Whilst the sub-Antarctic islands represent an exception to the general situation in the Southern Ocean regarding sovereignty and limitations on sovereignty created by the Antarctic Treaty, because of their remoteness and difficulty in enforcing relevant laws and regulations, they also fall within an effective legal vacuum.

Given this situation and the growing interest of bioprospectors in the region, it seems clear that the matter is in need of resolution especially as much of the subAntarctic Southern Ocean is potentially "deep seabed" for the purposes of the law of sea (Scovazzi 2006). In recent decades the ATS has taken a proactive role in seeking to fill gaps in the Antarctic legal regime prior to those weaknesses being exploited. Bioprospecting would seem to fall within that category and would be consistent with the initiatives taken to regulate the management of both living and nonliving resources especially in CCAMLR. The legal vacuum and the need for certainty may also invite other actors in the international community including the SPLOS, the ISBA, or the CBD COP to enter the field in order to resolve these issues.

\section{IUU fishing}

Notwithstanding the lengthy operation of the CCAMLR regime within the Southern Ocean and its acknowledged successes, during the past decade the phenomenon of IUU fishing has grown significantly (Baird 2004). IUU fishing is a global phenomenon which in the Southern Ocean is predominately conducted contrary to CCAMLR regulatory mechanisms. When the fishing activity is conducted within the EEZs of sub-Antarctic islands, it also will be in breach of the applicable laws and regulations regulating fishing activities within those waters. The rise in IUU fishing has resulted in considerable attention being given to the issue within CCAMLR and amongst those sub-Antarctic states seeking to protect the sub-regional fishery (Haward 2004). At the institutional level, CCAMLR has sought to respond by the adoption of enhanced measures to monitor fish stocks, vessel movements, and catch reporting data (Baird 2005). In this respect, CCAMLR has been increasingly drawn into what has become a global response amongst multiple regional fisheries management organisations against IUU fishing (High Seas Task Force 2006). The sub-Antarctic states have also been proactive, with Australia, France, New Zealand, and South Africa all individually and collectively seeking to deal with the issue (Abetz 2007). This reflects not only the concern amongst the sub-Antarctic states of illegal activity occurring within their region, but also the increased commercial interest in Southern Ocean fisheries (Batemen \& Rothwell 1998).

IUU fishing presents a particular challenge in the subAntarctic because of the relatively weak maritime regulation and enforcement mechanisms that within the region. When fishing is conducted under the CCAMLR framework the onus falls upon the flag state to ensure conformity with CCAMLR provisions. However, some flag states are more vigilant than others in the enforcement of their fisheries laws and this leads to uneven practices amongst some CCAMLR members. For non-CCAMLR members, their fishing vessels are able to operate within CCAMLR waters free of the constraints imposed by the Convention so as to effectively result in "unregulated" high seas fishing. Accordingly, the inherent weakness of the CCAMLR regime when dealing with a global industry such as fishing is a major reason why addressing IUU fishing in the region has proven so problematic. Even when IUÜ fishing is being conducted within sub-Antarctic EEZs that fall under the CCAMLR regime, notwithstanding that theoretically there exists a more viable law enforcement regime, the reality is that many of the sub-Antarctic states lack effective assets to actually enforce the law and bring the illegal fishers to account. This has certainly been the experience of Australia and France in their efforts to police IUU fishing in the waters adjacent to the Heard and Mc Donald islands and Kerguelen Island respectively. Even when arrests have been made, in some cases the legitimacy of the arrest and detention of the crew and vessel have been challenged in the International Tribunal for the Law of the Sea (Rothwell \& Stephens 2004).

Gradually the sub-Antarctic states have individually and collectively sought to tackle the problem of IUU fishing in the region. More assets have been deployed in a policing role including fixed-wing aircraft, patrol boats, naval craft, and in some instances specially fitted-out craft designed to be at sea in the Southern Ocean on lengthy patrols (Macdonald \& Ellison 2003). For France, its port facilities at Kerguelen have been an asset, whilst Australia with no viable port within the region has been forced to deploy assets to and from the mainland. South Africa and New Zealand, with their sub-Antarctic possessions less distant from their metropolitan territories have been more readily able to deploy patrols within their sub-Antarctic waters. With enforcement capacity significantly compromised in the sub-Antarctic due to climatic and environmental conditions plus the distance from operating bases, it is not surprising that several law enforcement operations against IUU fishers have raised significant legal and policy challenges. Australia, in particular, has been forced on two occasions to engage in long-distance hot pursuit of suspected illegal fishing vessels fleeing the sub-Antarctic; one pursuit ending off the coast of South Africa with the assistance of South African authorities and another ending in the South Atlantic (Molenaar 2004, Letts 2005). In response to these regional maritime enforcement challenges, Australia and France in 2003 entered into a treaty designed to enhance cooperative surveillance in the Southern Ocean, and in 2007 adopted an additional treaty to provide for cooperative enforcement of their respective fisheries laws (Abetz 2007). In addition, there have been ongoing discussions amongst Australia, France, New Zealand and South Africa regarding informal cooperative enforcement and surveillance mechanisms for the region. The result of these initiatives has been a strengthening of the legal enforcement regime to deal with IUU fishing in the sub-Antarctic. However gaps remain in the enforcement regime raising issues as to whether more comprehensive sub-regional enforcement mechanisms are necessary. 


\section{CONCLUDING REMARKS}

A feature of Antarctica's history including that of the Southern Ocean is that the region has been subject to waves of human exploitation. Initially the interest was driven by whales and seals. Throughout much of the Twentieth century it has been science that has been exploited in Antarctica, whilst more recently the interest has been in Southern Ocean fisheries. Bioprospecting may now be emerging as the new area of interest for the region, and just as all the drivers of human interest in Antarctica and the Southern Ocean have had repercussions for the sub-Antarctic so too will bioprospecting. This review has demonstrated that the sub-Antarctic, similarly to the region south of $60^{\circ} \mathrm{S}$ within the Antarctic Treaty framework, is subject to numerous overlapping and intersecting legal regimes which operate at a global, regional and national level. This creates a high level of complexity for managing the "international waters" of the sub-Antarctic, yet also provides a level of legal overlay that may not otherwise be possible in such a remote and underpopulated part of the world.

Whilst the legal regime to date has proven itself capable of managing the region despite some deficiencies in enforcement and regulation, there are looming issues on the horizon which may justify a rethink. Bioprospecting has been identified as one of those issues. Global legal frameworks have been established which actively encourage bioprospecting whilst respecting traditional state sovereignty. These frameworks are not easily transposed onto the Southern Ocean. CCAMLR may provide a possible framework for a response to Southern Ocean bioprospecting, otherwise the sub-Antarctic will be faced with a legal regime based predominantly on the freedom of scientific research under the law of the sea and little by way of sub-Antarctic regulation. Other horizon issues need to be considered. The resolution of extended continental shelf claims in the sub-Antarctic will result in greater certainty as to which parts of the sea-bed and ocean floor are under ISBA jurisdiction thereby opening up parts of the region to deep sea-bed mining. Whether such an activity is compatible with the environmental status of the region, and the potential environmental impact such an activity may have within the Antarctic Treaty area is questionable. Here the role of the ATS will be significant because of its capacity to represent the interests of the Antarctic region in international forums and to negotiate with the ISBA a moratorium on sub-Antarctic sea-bed mining activities.

Sub-Antarctic navigation is also a significant horizon issue because of the booming cruise industry and the existing and growing interest in tourist visits to sub-Antarctic islands. These activities not only raise questions of maritime safety and preparedness for search and rescue, but also whether there exist appropriate polar navigation standards in place for the Southern Ocean (Rothwell \& Joyner 2001). The increased presence of icebergs in the Southern Ocean as a possible consequence of global warming will also pose additional threats to both commercial and tourist vessels raising issues as to whether those vessels are properly equipped for the conditions. Finally, as with many current global issues there is an international security dimension to be considered. The region has previously been the scene of an international armed conflict during the 1982 Falklands War. Sovereignty disputes in the region, though muted, still remain. The threat of international terrorism cannot be dismissed, especially given the presence of large tourist vessels carrying predominantly Western passengers. All of which raises issues as to whether the sub-Antarctic and the management of its international waters is appropriately addressed under current international frameworks and mechanisms or whether there is a need for a new framework, either as an addition to the ATS or one which has a distinctive sub-Antarctic focus. This will not be an easy issue to resolve. However the fact remains that the issues confronting the region are as significant as those which have faced the Antarctic in the past, and accordingly a coordinated regional response of some form seems appropriate.

\section{ACKNOWLEDGEMENTS}

The support of the Faculty of Law, University of Sydney in providing funds to travel to and participate in the $2006 \mathrm{Hobart}$ International Forum on the sub-Antarctic is acknowledged. This paper draws upon work previously undertaken at the Sydney Centre for International and Global Law, University of Sydney between 2004 and 2006. The assistance of Dr Shirley Scott, Dr Alan Hemmings and Dr Tim Stephens is acknowledged.

\section{CASES}

The Volga Case 2002: Russian Federation v. Australia ITLOS Case No. 11, 23 December 2002. 2003: International Legal Materials 42: 159.

\section{TREATIES}

Agreement on the Conservation of Albatrosses and Petrels 2001: Australian Treaty Series 5.

Antarctic Treaty 1959: United Nations Treaty Series 402: 71.

Convention Concerning the Protection of the World Cultural and Natural Heritage 1972: United Nations Treaty Series 1037: 151.

Convention for the Conservation of Southern Bluefin Tuna 1994: Australian Treaty Series 16.

Convention on Biological Diversity 1992: International Legal Materials 31: 818 .

Convention on the Conservation of Antarctic Marine Living Resources 1980: United Nations Treaty Series 1329: 47.

International Convention for the Prevention of Pollution from Ships 1973: International Legal Materials 12: 1319.

International Convention for the Regulation of Whaling 1946: United Nations Treaty Series 161: 74 .

Protocol on Environmental Protection to the Antarctic Treaty 1991: International Legal Materials 30: 1455.

Treaty between the Government of Australia and the Government of the French Republic on cooperation in the maritime areas adjacent to the French Southern and Antarctic Territories (TAAF), Heard Island, and the McDonald Islands 2005: Australian Treaty Series 6.

LOS Convention - United Nations Convention on the Law of the Sea 1982: United Nations Treaty Series 1833: 396.

\section{REFERENCES}

Abetz, E. 2006: A sustainable future for the highly-prized Patagonian toothfish. Media Release DAFF06/007A (4 March 2006).

Abetz, E. 2007: Australia and France sign treaty to step up the flight against illegal fishing. Media Release DAFF07/003A (9 January 2007). 
Baird, R. 2004: Illegal, unreported and unregulated fishing: an analysis of the legal, economic and historical factors relevant to its development and persistence. Melbourne Journal of International Law 5: 299-334.

Baird, R. 2005: CCAMLR initiatives to counter flag-state non enforcement in southern ocean fisheries. Victoria University of Wellington Law Review 36: 733-755.

Batemen, S. \& Rothwell, D.R. (eds) 1998: Southern Ocean Fishing: Policy Challenges for Australia. Centre for Maritime Policy, University of Wollongong, Wollongong: $142 \mathrm{pp}$.

Birnie, P. \& Boyle, A. 2002: International Law and the Environment. 2nd edition. Oxford University Press, Oxford: 798 pp.

Blay, S. \& Bubna-Litic, K. 2006: The interplay of international law and domestic law: The case of Australia's efforts to protect whales. Environmental and Planning Law Journal 23: 465 .

Churchill, R.R. \& Lowe, A.V. 1999: The Law of the Sea. 3rd edition. Manchester University Press, Manchester: 494 pp.

Commonwealth of Australia 2004: Continental Shelf Submission of Australia: Executive Summary. Commonwealth of Australia, Canberra: 42 pp.

Downer, A., Ruddock P. \& Macfarlane I. 2004: Joint media release - Australia lodges Continental Shelf submission (16 November 2004) at <www.foreignminister.gov.au/ releases/2004/joint_continental_shelf_submission> (29 April 2005).

Farrell, R.L. \& Duncan, S.M. 2005: Uniqueness of Antarctica and potential for commercial success. In Hemmings, A.D. \& Rogan-Finnemore, M. (eds): Antartic Bioprospecting. Gateway Antarctica, University of Canterbury, Christchurch: 10-40.

France 2005: Note No. 05.29130 - Permanent Mission of France to the United Nations, (28 March 2005) at <www. un.org/Depts/los/clcs_new/submissions_files/aus04/ clcs_03_2004_los_fra_en.pdfs (4 January 2007).

Guyomard, A. 2006: Bioprospecting in Antarctica: a new challenge for the Antarctic Treaty System. In Francioni, F. \& Scovazzi, T. (eds): Biotechnology and International Law. Hart Publishing, Oxford: 147-169.

Hall, H.R. 2007: The politics of albatross and petrel conservation. In Lorne K. Kriwoken et al. (eds): Looking South: Australia's Antarctic Agenda. The Federation Press, Annandale: in press.

Haward, M. 2004: IUU fishing: contemporary practice. In Oude Elferink, A.G \& Rothwell, D.R. (eds): Oceans Management in the 21st Century: Institutional Frameworks and Responses. Martinus Nijhoff, Leiden: 87-106.

Hemmings, A. 2006: Regime overlap in the Southern Ocean: the case of Southern Bluefin Tuna and CCSBT in the CCAMLR Area. New Zealand Yearbook of International Law 3: 207-217.

Hemmings, A. \& Rogan-Finnemore, M. 2005: Antarctic Bioprospecting. Gateway Antarctica, University of Canterbury, Christchuch: 351 pp.

High Seas Task Force 2006: Closing the Net: Stopping Illegal Fishing on the High Seas. "Task Force on IUU Fishing on the High Seas, London: $21 \mathrm{pp}$.

Jabour, J. 2006: High latitude diplomacy: Australia's Antarctic extended continental shelf. Marine Policy 30: 197-198.

Jabour-Green, J. \& Nicol, D. 2003: Bioprospecting in areas outside national jurisdiction: Antarctica and the Southern Ocean. Melbourne Journal of International Law 4: 76-111.

Johnson, S. \& Lohan, D. 2005: Existing activities, policies and emerging issues for the Antarctic Treaty System. In Hemmings, A.D. \& Rogan-Finnemore, M. (eds): Antarctic Bioprospecting. Gateway Antarctica, University of Canterbury, Christchurch: 130-206.

Joyner, C.C. 1986. Legal implications of the common heritage of mankind. International and Comparative Law Quarterly 35: 190.
Joyner, C.C. 1992: Antartica and the Law of the Sea. Martinus Nijhoff Publishers, Dordrecht: $302 \mathrm{pp}$.

Kaye, S.B. 2001a: The outer Continental Shelf in the Antarctic. In Oude Elferink, A.G. \& Rothwell, D.R. (eds): The Law of the Sea and Polar Maritime Delimitation and Jurisdiction. Martinus Nijhoff Publishers, The Hague: 125-137.

Kaye, S.B. 2001b: International Fisheries Management. Kluwer Law International: The Hague: 606 pp.

Kaye S.B. \& Rothwell D.R. 2002: Southern Ocean boundaries and maritime claims: another Antarctic challenge for the Law of the Sea? Ocean Development and International Law 33: 359-389.

Kwiatkowska, B. \& Soons, A.H.A. 1990: Entitlement to maritime areas of rocks which cannot sustain human habitation or economic life of their own. Netherlands Yearbook of International Law 21: 139.

Letts, D. 2005: Recent Australian experience of the Law of the Sea and military operations. Australian Year Book of International Law 24: 129-144.

McDorman, T.L. 2002: The role of the Commission on the Limits of the Continental Shelf: a technical body in a political world. International Joumal of Marine and Coastal Law 17: 301 .

Macdonald, I. \& Ellison, C. 2003: Permanent armed patrols to toughen border protection in Southern Ocean. Media Release AFFA03/277MJ (17 December 2003).

Molenaar, E.J. 2001: CCAMLR and southern ocean fisheries. International Journal of Marine and Coastal Law 16: 465-499.

Molenaar, E.J. 2004: Multilateral hot pursuit and illegal fishing in the Southern Ocean: the pursuits of the Virasa I and the South Tomi. International Journal of Marine and Coastal Law 19: 19-42.

New Zealand 2006a: Note Number: NZ-CLCS-TPN-02 (19 April 2006). New Zealand Permanent Mission to the United Nations, New York: 2 pp.

New Zealand 2006b: New Zealand Submission to the Commission on the Limits of the Continental Shelf pursuant to article 76 (8) of the United Nations Convention on the Law of the Sea. Government of New Zealand, Wellington: $80 \mathrm{pp}$.

Opeskin, B.R. \& Rothwell, D.R. 1991: Australia's Territorial Sea: International and Federal implications of its extension to 12 miles. Ocean Development and International Law 22: 395-431.

Orrego Vicuña, F. 1992: The "Presential Sea": defining coastal states" special interests in high seas fisheries and other activities. German Yearbook of International Law: 264--292.

Orrego Vicuña, F. 1996: The regime of Antarctic marine living resources. In Francioni, F. \& Scovazzi, T. (eds): International Law for Antartica. 2nd edition. Kluwer Law International, The Hague: 127-157.

Oude Elferink, A.G. 2002: The Continental Shelf of Antarctica: implicarions of the requirement to make a submission to the CLCS under Article 76 of the LOS Convention. International Journal of Marine and Coastal Law 17: $485-520$.

Oude Elferink, A.G. 2004: Reviewing the implementation of the LOS Convention: the role of the United Nations General Assembly and the meeting of the states parties. In Oude Elferink, A.G \& Rothwell, D.R. (eds): Oceans Management in the 21st Century: Institutional Frameworks and Responses. Martinus Nijhoff, Leiden: 295-312.

Oude Elferink, A.G. \& Rothwell, D.R. (eds) 2001: The Law of the Sea and Polar Maritime Delimitation and Jurisdiction. Martinus Nijhoff Publishers, The Hague: 382 pp.

Rothwell, D.R. \& Joyner, C.C. 2001: The Polar oceans and the Law of the Sea. In Oude Elferink A. G. \& Rothwell D. R. (eds): The Law of the Sea and Polar Maritime Delimitation and Jurisdiction. Martinus Nijhoff Publishers, The Hague: 1-22. 
Rothwell, D.R. \& Scott, S.V. 2007: Flexing Australian sovereignty in Antarctica: pushing Antarctic Treaty limits in the national interest. In Lorne K. Kriwoken et al. (eds): Looking South: Australia's Antarctic Agenda. The Federation Press, Annandale: in press.

Rothwell, D.R. \& Stephens, T. 2004: Illegal Southern Ocean fishing and prompt release: balancing coastal and flag state rights and interests. International and Comparative Law Quarterly 53: 171-187.

Rothwell, D.R. 2004: The Southern Ocean: environmental and resource management under international law. In Smith, H.D. (ed.): The Oceans: Key Issues in Marine Affairs. Kluwer Academic Publishers, Dordrecht: 297-311.

Scovazzi, T. 1996: The Antarctic Treaty System and the new Law of the Sea: selected questions. In Francioni, F. \& Scovazzi, T. (eds): International Law for Antarctica. 2nd edition. Kluwer Law International, The Hague: 377-394.
Scovazzi, T. 2006: Bioprospecting on the Deep Seabed: a legal gap requiring to be filled. In Francioni, F. \& Scovazzi, T. (eds): Biotechnology and International Law. Hart Publishing, Oxford: 81-97.

Vigni, P. 2006: Antarctic bioprospecting: Is it compatible with the value of Antarcrica as a natural resource? In Francioni, F. \& Scovazzi, T. (eds): Biotechnology and International Law. Hart Publishing, Oxford: 111-145.

Zovko, I. 2005: The International liability and compensation regimes relating to vessel-sourced pollution of the marine environment: case study of the Southern Ocean. New Zealand Yearbook of International Law 2: 281-326.

(accepted 28 May 2007) 